\title{
An Overview of Corporate Governance Practice in Companies Listed on the Libyan Stock Market
}

\author{
By Salem Amara*
}

The corporate governance concept has recently become a major issue in the corporate practices of both developed and developing countries alike. Corporate governance is considered to be a tremendously important topic in many countries around the world; specifically within the emerging stock markets in order to protect the minority of shareholders. The aim of this research is to investigate corporate governance practices in companies listed on the Libyan stock exchange. In particular, to investigate whether corporate governance practices in these companies meet international standards of corporate governance and to identify the main obstacles to implementing them. The concept of corporate governance, corporate governance practices in developing countries, the Libyan stock market and OECD principles of corporate governance were discussed. A close-ended questionnaire was the main method for data collection. 100 questionnaires were distributed to the participants of the study, and only 76 questionnaires usable for analysis were received. Several issues related to corporate governance, depending on OCED principles, were investigated. The results revealed that corporate governance practice in the companies under investigation fit with OCED principles of corporate governance in some aspects and do not fit in others. Furthermore, the most important obstacles were perceived impeding corporate governance practice in companies listed in the Libyan stock market are "lack of compliance with the laws governing the work of companies" and "high cost of applying corporate governance rules". (JEL G30)

Keywords: Corporate governance, the Libyan stock exchange, developing countries, OCED principles of corporate governance

\section{Introduction}

Corporate governance is not merely the governing of a certain form of organization "a corporation", but also has a broader meaning. The concept has been used by different scholars differently and still there is no a universally accepted definition of corporate governance (Rezaee 2009). Corporate governance has gained attention of governments since 1990 after the financial scandals witnessed by western economies such as Enron, WorldCom and Paramalat which were facilitated by wrongdoings on the part of the management, auditors and financial market operatives. This paper is organized as follows: reviews of existing studies, study questions, study objectives, the concept of corporate governance, corporate governance practices in developing countries, the Libyan stock market,

*Assistant Professor, Accounting Department, Sabratha University, Libya. 
OECD principles of corporate governance, research methodology, findings and discussion; and lastly the study's conclusion.

\section{Review of Existing Studies}

For the protection of shareholders, corporate governance has been the main area of research during the last three decades. During 1970s, scholars discussed and debated the role of government in promoting managers and board's responsibility. In the 1980s, the best methods of corporate governance were market control mechanisms. Later in the 1990s, the activism of institutional investors emerged as a way to hold managers and boards responsible. Ultimately, recent discussions have focused on the convergence of a global corporate governance regime (Al-Wasmi 2011, p.10). The available literature on corporate governance in developing countries is little compared with the existing literature in developed countries (Charles and Oludele 2003, p.2). In this regard, some studies related to corporate governance will be mentioned in section No .6 (corporate governance in developing countries). In Libya, according to the researcher's knowledge, the studies regarding corporate governance practices were limited. Accordingly, this study covers one aspect of corporate governance concerning companies listed on the Libyan Stock Market.

\section{Study Questions}

In relating to the study problem, study present the following questions:

1. What is the nature of corporate governance practices of the companies listed on the Libyan Stock Market?

2. What are the main obstacles that face corporate governance practices of these companies?

\section{Study Objectives}

The above questions indicate that the study is twofold. Firstly, to explore the nature of corporate governance practices of the companies listed on the Libyan Stock Market. Several issues will be investigated depending on OCED principles. Secondly, to investigate obstacles associated with the corporate governance practices of the target companies.

\section{The Concept of Corporate Governance}

The concept or the definition of corporate governance differs from country to another and from study to another, as each corporate system or theory has its own definition (Solomon and Solomon 2004, p.13). Du Plessis et al. (2005) stated that there is no universally accepted or definite meaning of corporate governance. Many scholars and organizations have their own definitions. Each such definition 
has been founded according to the understanding or the interests of the person provided the definition. The differences among the definitions of the concept of corporate governance can be slight or fundamental. In contrast, some observers find the concept of corporate governance difficult to define. Keasey et al. (1997, p.22) have identified the inconsistent use of the term 'corporate governance' by different authors and were unable to find any real consensus among scholars about the definition of the concept. Mehran (2003, p.1), for example, illustrated that "The term 'corporate governance' essentially refers to the relationships among management, the board of directors, shareholders, and other stakeholders in a company. These relationships provide a framework within which corporate objectives are set and performance is monitored ". Rezaee (2009, p.29) provided a comprehensive definition of corporate governance, where it is looked at as "the process affected by a set of legislative, regulatory, legal, market mechanisms, listing standards, best practices, and efforts of all corporate governance participants, including the company's directors, managers, auditors, legal counsel, and financial advisors, which creates a system of checks and balances with the goal of creating and enhancing enduring and sustainable shareholder value, while protecting the interests of other stakeholders". Corporate governance has also been defined as: "The system of checks and balances, both internal and external to companies, which ensures that companies discharge their accountability to all their stakeholders and act in a socially responsible way in all aspects of their business activity" (Solomon 2010, p.14). The Cadbury Report of the Financial Aspects of Corporate governance, December 1, 1992, defined corporate governance as "The system by which companies are directed and controlled" (Al-Wasmi 2011, p.16). The Organization for Economic Co-Operation and Development (OECD) has provided a practical definition of corporate governance, that is: "Corporate governance involves a set of relationships between a company's management, its board, its shareholders and other stakeholders. Corporate governance also provides the structure through which the objectives of the company are set, and the means of attaining those objectives and monitoring performance are determined" (Clarke 2004, p.1).

According to the definitions mentioned above, the concept of corporate governance ranges between narrow and wide concepts. The narrow approach concerns the relationships between corporate managers, boards of directors and shareholders; for example, Sternberg (2004, p.28) stated that: "Corporate governance describes ways of ensuring that corporate actions, agents and assets are directed at achieving the corporate objective established by the corporation's shareholders". A narrow view of corporate governance restricts the concept merely to the relationship between the business corporation's management and its owners, the shareholders. This view is reflected in the Agency Theory (Solomon and Solomon 2004). Baklouti et al. (2016) observed that the agency theory is an analytical expression of the contractual relationship existing between two parties. On the other hand, the wide definition of corporate governance imposes upon the business corporation responsibility for its shareholders, stakeholders and its entire community (Solomon and Solomon 2004). In this regard, a broader view includes the stakeholders of the business corporation such as employees, suppliers, 
creditors, customers, in addition to the corporation management and shareholders (Solomon and Solomon 2004, p.12). Accordingly, this definition reflects the Stakeholder Theory. Therefore, the current theorising on corporate governance has been polarised between a shareholder perspective "narrow view" and a stakeholder perspective "broad view" (Letza et al. 2004). Consequently, we can summaries that when defining corporate governance, the definition must include the best practices of corporate governance, in addition to every constituent with a stake in the corporation's business, and the policy and decision making procedures.

\section{Corporate Governance Practices in Developing Countries}

Corporate governance can be defined as a complex system consisting of laws, regulations, politics, public institutions, professional associations and codes of ethics (Aldabbous 2012). Although, it has been built gradually over centuries in developed countries, a lot of the details of this system, in developing countries, are still missing. Aldabbous (2012) stated that developing corporate governance practice in developing countries is difficult due to a variety of problems such as complex corporate ownership structures, unclear and confusing relationships between the stakeholders, weak legal and judicial systems, absent or underdeveloped institutions and limited human resource capabilities. Much research has recently examined the corporate governance practices in developing countries. For example, Da Silveira et al. (2007) analyzed the firm-level corporate governance practices in Brazil and found no clear evidence that ownership structure, growth opportunity, company size, and company value influence corporate governance practices (except for the fact that ownership structure itself can be regarded as a governance mechanism). Lazarides et al. (2009) analyzed corporate governance practices in Greece and examined the relationship between ownership structure and corporate governance practices in Greece. The results showed that ownership structure is affected by the balance of power and control within the firm. Corporate governance does not seem to have any significant effect on ownership structure. Alas et al. (2010) illustrated that the corporate governance practices enabled decision-makers in Estonia to discuss different mechanisms of owner influence and to define the owner's position in the organizational change. They conclude that the role of management and supervisory boards in the corporate governance model adopted in Estonia led to the influence of ownership on organizational change. In Malaysia, Liew's study showed that Malaysia's corporate governance practices have been developed on the Western model. However, the majority of the interviewees of the study placed emphasis on the social characteristics of corporate governance, in contrast to the usual idea of shareholder accountability. Furthermore, the study explained that, without changes in the corporate culture, it is doubtful whether good corporate governance practices will be achieved (Liew 2007). In Bangladesh, some projects have been undertaken to develop corporate governance practices but many of these are inadequate. The corporate infrastructure is dysfunctional in most, if not all, aspects. Whilst the legal system appeared to be weak, a general ineffectiveness, political and other socio-economic factors are also working as major obstacles for 
the development of corporate governance standards in Bangladesh (Chowdhury Saima 2013). In 2009 a study was conducted by Andreasson to explore the current corporate governance practices in South Africa. He found that the lack of institutional capacity plays an important role in shaping corporate governance structure in South Africa. The study, also, clarified the fact that the problems associated with the lack of institutional capacity lie behind the weak corporate governance practices in their country (Andreasson 2009). In addition, Wanyama et al. (2009) investigated the corporate governance practices in the developing African nation of Uganda. Their results show that the simple emergence of detailed governance codes in developing countries does not necessarily mean improvement in real practices will improve. The Ugandan corporate governance framework has not been strong enough to support "good" practice. They conclude that improving governance practices requires more than publishing of codes. Therefore, root changes should be made in the contextual factors, including at the political and cultural levels. In Nigeria, the findings of a study was undertaken by Okpara (2011) provide important information on corporate governance and reveal a number of constraints that are delaying its implementation. These constraints include weak or non-existent law enforcement mechanisms, the abuse of shareholders' rights, a lack of commitment on the part of boards of directors, a lack of adherence to the regulatory framework, weak enforcement and monitoring systems, and a lack of transparency and disclosure. As for Arabic countries, Bahrain for instance, the Bahraini companies had adopted some of the features of corporate governance best practice, such as boards dominated by non-executive directors and the separation of the roles of chair and chief executive officer. Yet, none of the Bahraini companies had a nominations committee, and, therefore, nonexecutive directors were usually nominated by major shareholders. Furthermore, the non-executive directors in the majority of companies were not former executive board members. In general, Bahraini companies had a number of key corporate governance structural features, but further progress still needs to be made (Hussain and Mallin 2002).

\section{The Libyan Stock Market}

According to Singh (2003), most developing countries do not have active corporate control markets in the Western. These markets are likely to suffer from more informational deficits than markets in countries such as the US and the UK. It has been widely acknowledged that the weakness of corporate governance is one of the most important reasons for the economic crisis in developing markets. The Libyan Stock Market (LSM) was established by Decision No. (134) of the General People's Committee, on June 3, 2006, to form a joint stock company with a capital of 20 million Libyan dinars, divided into 2 million shares with a nominal value of 10 LD per share ${ }^{1}$. The first phase focused on introducing financial definitions and rules, the addition of several workshop courses, and a series of agreements with the Amman Stock Exchange, Cairo \& Alexandria Stock Exchange and the Egyptian Company for Clearance and deposit. Listed companies include Sahara

\footnotetext{
${ }^{1}$ https://cbl.gov.ly/wp-content/uploads/2016/03.
} 
Bank, Wahda Bank, Commerce and Development Bank, Assaray Bank, the Libyan Insurance Company, the United Insurance Company, Sahara Insurance Company, the Libyan Stock Market, the Libyan Tobacco Company Contribution, and the Development Company for Medicine Manufacturing and Medical products $^{2}$. IN $18^{\text {th }}$ of October 2007, a cooperation agreement was signed in London between the Libyan Stock Exchange Market and London Stock Exchange. The agreement provides for training teams of the Libyan Stock Exchange in Tripoli and in London to enable them to run the stock market operations. In addition, there will be regular reviews of the Libyan regulations and systems to update them, and for seminars and conferences organized by the London Stock Exchange. The Libyan Stock Market was closed following the eruption of the events took place in Libya in 2011, until it has been reopened on 15 march 2012. However, LSM recently Joining the membership of the following: Arab Securities Exchange Association (ASEA), African and Middle East Depository Agency (AMEDA), Association of Numbering Agencies (ANN), Association of African Exchange (AAE), and World Federation of Exchanges (WFE) (Aljbiri 2012) ${ }^{3}$.

\section{OECD Principles of Corporate Governance}

For the best practice of corporate governance, a set of principles and guidelines have been introduced by some international organizations. The Organization for Economic Co-operation and Development (OECD), for instance, introduced principles of corporate governance in 1999. These principles were revised in 2004 to be compatible with financial and economic developments and since then they have become a benchmark for corporate governance in many countries of the world (Al-Wasmi 2011). In this regard, the International Association of Insurance Supervisors (IAIS) uses the OECD principles of corporate governance as a benchmark; hence all member countries must implement these principles (Tosuni 2013). The first set of OECD corporate governance principles consisted of only five subheadings, whereas the final version (2004) has the following six subheadings ${ }^{4}$ :

1. Ensuring the Basis for an Effective Corporate Governance Framework.

2. The Rights of Shareholders and Key Ownership Functions.

3. The Equitable Treatment of Shareholders.

4. The Role of Stakeholders in Corporate Governance.

5. Disclosure and Transparency.

6. The Responsibilities of the Board.

Each of the principles listed above is supported by additional sub-principles which are intended to clarify the purpose of the principle and help the interested parties with the implementation in practice. These principles are updated with experiences from OECD area and non OECD countries to accommodate the legal

\footnotetext{
${ }^{2}$ http://www.lsm.ly/English/Inclusion/Page/IncludedCompanies.aspx. ${ }^{3}$ http://www.lsm.ly/Arabic/managment/Pages/History.aspx.

${ }^{4}$ The OECD Principles of Corporate Governance (1999) and (2004), available at: www.oecd.org.
} 
and cultural circumstances and differences. Furthermore, the principles are designed to provide guidance for stock exchanges, corporations, investors and other parties of interest with a role in the building good corporate governance (OECD 2004). Lastly, for the purpose of this study, the questionnaire was designed according to these principles.

\section{Research Methodology}

A close-ended questionnaire was the primary technique for collecting data from the sample of the study about their attitudes and perceptions about the nature and obstacles of corporate governance practice. Executive company chairmen, non-executive company chairmen, chief executive officers, executive directors, non-executive directors, company managers, financial managers and financial officers were the population of the study ${ }^{5} .100$ questionnaires were distributed to the participants of the study (10 for each company).76 questionnaires usable for analysis were received with percentage of $76 \%$. Most of the questions were constructed on a five-point rating scale (Likert scale) format, and the Statistical Package for Social Sciences (SPSS) was utilized for data analysis. Descriptive statistics included the frequencies; mean and standard deviation were computed for the statements that included in the questionnaire.

\section{Findings and Discussion}

The first part of this section presents the participants' information followed by the questionnaire analysis.

\section{General Information of Participants}

A number of questions were included in the questionnaire in order to obtain general information about each respondent which could provide some indications as the reliability of the responses given. This information includes age, job titles and academic qualifications as shown in table 1 below.

\section{Participants' Age}

As shown in Table 1, only $3(3.9 \%)$ of the individual respondents being younger aged 30, while $18(23.7 \%)$ were in the 30-40 age group, with $55(72.4 \%)$ being in the over 50 age group, which indicating they were likely to be more experienced.

\footnotetext{
${ }^{5}$ The questionnaire survey was distributed to companies' top management and key personnel positions because they are all involved in managing and/or controlling companies; they are also responsible for setting out a practical methodology for implementing and monitoring corporate governance systems in their companies.
} 
Participants' Job Title

Table 1 below, stated that all participants are associated with the subject of corporate governance, whereas $29(38.1 \%)$ of them were at companies' top management and key personnel positions, while the other 47 (61.9\%) were financial officers. Accordingly, one can expected the data provided by such participants to be highly relevant to the issues raised in this study.

\section{Participants' Academic Qualifications}

As can be seen from the table below, the majority (48.7\%) of the respondents held higher degrees (34.2\% held a Master's degree and 14.5\% held PhDs degree), while (44.7\%) held a Bachelor's degree and only (6.6) held a Diploma's degree. In this regard, the participants seem to be objectively and effectively serve the study aims and provide support for it.

Table 1. Participants' Age, Job Title and Academic Qualification

\begin{tabular}{|c|c|c|c|c|c|c|c|c|}
\hline Age & no & $\%$ rate & Job title & No & $\%$ rate & $\begin{array}{c}\text { Academic } \\
\text { qualification }\end{array}$ & no & $\begin{array}{c}\% \\
\text { rate }\end{array}$ \\
\hline $20-30$ & 3 & 3.9 & $\begin{array}{l}\text { Executive } \\
\text { Company } \\
\text { Chairman }\end{array}$ & 2 & 2.6 & $\mathrm{PhD}$ & 11 & 14.5 \\
\hline $30-40$ & 18 & 23.7 & $\begin{array}{c}\text { non-executive } \\
\text { company chairman }\end{array}$ & 2 & 2.6 & Master & 26 & 34.2 \\
\hline $40-50$ & 37 & 48.7 & $\begin{array}{c}\text { chief executive } \\
\text { officers }\end{array}$ & 4 & 5.3 & Bachelor & 34 & 44.7 \\
\hline $50-60$ & 14 & 18.4 & executive directors & 3 & 3.9 & Diploma & 5 & 6.6 \\
\hline $\begin{array}{l}\text { Age > } \\
60\end{array}$ & 4 & 5.3 & $\begin{array}{l}\text { non-executive } \\
\text { directors }\end{array}$ & 5 & 6.6 & ------- & --- & --- \\
\hline $\begin{array}{ll}------ \\
\end{array}$ & --- & --- & company managers & 3 & 3.9 & ------- & --- & --- \\
\hline ------- & --- & --- & financial managers & 10 & 13.2 & ------- & --- & --- \\
\hline ------- & --- & --- & financial officers & 47 & 61.9 & ------- & --- & --- \\
\hline Total & 76 & $\% 100$ & Total & 76 & $\% 100$ & Total & 76 & $\% 100$ \\
\hline
\end{tabular}

Source: Researcher's Design.

Nature of Corporate Governance in Companies Listed on the Libyan Stock Market

Six elements (OECD Principles) related to the nature of corporate governance were examined. These elements are: (1) ensuring the basis for an effective corporate governance framework (ownership structure and control); (2) the rights of shareholders and key ownership functions (shareholders rights); (3) the equitable treatment of shareholders (accountability); (4) the role of stakeholders in corporate governance (stakeholders role); (5) disclosure and transparency; (6) the responsibilities of the board (the board of director) ${ }^{6}$. As for data analysis, measure of central tendency (mean), which was computed for all statements included in the questionnaire are interpreted according to the range of each scale. Hence, the extension of Likert scale is determined by $5-1=4$, and in order to identify the

\footnotetext{
${ }^{6}$ Note: Respondents were asked to indicate their opinion on a five-point scale ranging from strongly disagree to strongly agree (1=strongly disagree; $2=$ disagree; $3=$ undecided; $4=$ agree; $5=$ strongly agree).
} 
length of each scale " $b$ " was computed ( $b=4 / 5=0.80)$. Accordingly, the range of each scale used in this study was: 1 to 1.80 represents "strongly disagree", 1.81 to 2.60 represents "disagree", 2.61 to 3.40 represents "undecided", 3.41 to 4.20 represents "agree" and 4.21 to 5 represents "strongly agree".

\section{Ownership Structure and Control}

A list of six statements was provided to participants who were asked to indicate the extent to which they agreed with each of these statements (see Table 2).

Table 2. Respondents' Opinion about Ownership Structure and Control

\begin{tabular}{|c|c|c|c|c|c|}
\hline $\mathbf{N}$ & Statements & No. of cases & Mean & Rank & $\begin{array}{c}\text { Std. } \\
\text { Deviation } \\
\end{array}$ \\
\hline 1 & $\begin{array}{l}\text { There are so-called } \\
\text { major shareholders } \\
\text { in my company. }\end{array}$ & 76 & 4 & 2 & 1.095 \\
\hline 2 & $\begin{array}{l}\text { Major shareholders } \\
\text { control and have a } \\
\text { direct influence over } \\
\text { company's activities. }\end{array}$ & 76 & 4.368 & 1 & 0.846 \\
\hline 3 & $\begin{array}{l}\text { One or two large } \\
\text { shareholders } \\
\text { collectively control } \\
\text { the company. }\end{array}$ & 76 & 3.816 & 4 & 1.016 \\
\hline 4 & $\begin{array}{l}\text { Ownership is } \\
\text { dispersed In my } \\
\text { company with no } \\
\text { controlling } \\
\text { shareholder, and the } \\
\text { management is not } \\
\text { directly controlled } \\
\text { by shareholders. }\end{array}$ & 76 & 1.592 & 6 & 0.836 \\
\hline 5 & $\begin{array}{l}\text { CEO has a great deal } \\
\text { of power in my } \\
\text { company. }\end{array}$ & 76 & 3.974 & 3 & 0.993 \\
\hline 6 & $\begin{array}{l}\mathrm{CEO}^{7} \text { does not } \\
\text { participate much in } \\
\text { making fundamental } \\
\text { decisions pertaining } \\
\text { to the company. }\end{array}$ & 76 & 2.368 & 5 & 1.056 \\
\hline
\end{tabular}

Source: Researcher's Design.

As can be seen through Table 2, respondents indicated with "strongly agree" that major shareholders have control and a direct influence over companies' activities (mean score and standard deviation are 4.368, 0.846); and that attributed to the fact that there are so-called major shareholders in my company, as

${ }^{7} \mathrm{CEO}=$ Chief Executive Officer. 
respondents illustrated with "agree" (mean score and standard deviation are 4, 1.095). In addition, statements $(5,3)$ "CEO has a great deal of power in my company" and "One or two large shareholders collectively control the company" received an agreement "agree" (mean score are 3.974, 3.816 respectively); while statements $(4,6)$ received an agreement "strongly disagree" and "disagree" (mean score 1.592, 2.368 respectively). Accordingly, the ownership structure in companies listed on the Libyan stock market is concentrated. Hence, these norms fit poorly with the principles of OCED corporate governance standards, which stress the equal rights of all shareholders.

\section{Shareholders Rights}

In this section participants were asked to give their opinions about eight statements which represent shareholders rights.

Table 3. Respondents' Opinion about Shareholders Rights

\begin{tabular}{|c|c|c|c|c|c|}
\hline $\mathbf{N}$ & Statements & $\begin{array}{l}\text { No. of } \\
\text { cases }\end{array}$ & Mean & Rank & $\begin{array}{c}\text { Std. } \\
\text { Deviation }\end{array}$ \\
\hline 1 & $\begin{array}{l}\text { Shareholders obtain relevant } \\
\text { information about the company on a } \\
\text { timely and regular basis. }\end{array}$ & 76 & 3.961 & 6 & 0.840 \\
\hline 2 & $\begin{array}{l}\text { Shareholders elect members of the } \\
\text { board. }\end{array}$ & 76 & 4.487 & 2 & 0.643 \\
\hline 3 & $\begin{array}{l}\text { Shareholders share in the profits of the } \\
\text { company. }\end{array}$ & 76 & 4.566 & 1 & 0.549 \\
\hline 4 & All shareholders are treated equally. & 76 & 4.224 & 3 & 0.842 \\
\hline 5 & $\begin{array}{l}\text { All shareholders have the same voting } \\
\text { rights. }\end{array}$ & 76 & 3.789 & 8 & 0.928 \\
\hline 6 & $\begin{array}{l}\text { Process and procedures for general } \\
\text { shareholder meetings allow for } \\
\text { equitable treatment of all shareholders. }\end{array}$ & 76 & 4.223 & 4 & 0.645 \\
\hline 7 & $\begin{array}{l}\text { Shareholders are provided with } \\
\text { adequate information on the agenda } \\
\text { items of the shareholders' meeting. }\end{array}$ & 76 & 4.039 & 5 & 0.701 \\
\hline 8 & $\begin{array}{l}\text { It is not difficult to discover how much } \\
\text { equity ownership the major } \\
\text { shareholders control. }\end{array}$ & 76 & 3.908 & 7 & 0.636 \\
\hline
\end{tabular}

Source: Researcher's Design.

Table 3 indicates a high level of the participants' agreement "strongly agree" for some shareholders rights represented in statements $(2,3,4,6)$, "Shareholders elect members of the board", " Shareholders share in the profits of the company", "All shareholders are treated equally" and "Process and procedures for general shareholder meetings allow for equitable treatment of all shareholders" with mean scores greater than 4.20. As for the other four statements related to shareholders rights which listed in Table 3, "Shareholders obtain relevant information about the company on a timely and regular basis", "All shareholders have the same voting rights", "Shareholders are provided with adequate information on the agenda items of the shareholders' meeting" and "It is not difficult to discover how much equity 
ownership the major shareholders control" received an agreement "agree" (mean= 3.961, 3.789, 4.039 and 3.908 respectively). According to the above discussion, companies listed on the Libyan stock market protect shareholders rights. Hence, these norms fit with the principles of OCED corporate governance standards, which stress the protection of shareholders rights.

\section{Accountability}

Respondents, in this question, were asked "To what extent do you agree that your company's Board is accountable for the following?" Table 4 below illustrates respondents' perceptions about this issue.

Table 4. Respondents' Opinion about Accountability

\begin{tabular}{|l|l|c|c|c|c|}
\hline $\mathbf{N}$ & Statements & $\begin{array}{c}\text { No. of } \\
\text { cases }\end{array}$ & Mean & Rank & $\begin{array}{c}\text { Std. } \\
\text { Deviation }\end{array}$ \\
\hline 1 & Shareholders & 76 & 4.605 & 1 & 0.492 \\
\hline 2 & Auditors & 76 & 4.539 & 2 & 0.502 \\
\hline 3 & Customers & 76 & 4.039 & 4 & 0.791 \\
\hline 4 & Suppliers & 76 & 4.013 & 5 & 0.757 \\
\hline 5 & Employees & 76 & 4.513 & 3 & 0.577 \\
\hline 6 & The regulatory and monitoring bodies & 76 & 3.671 & 7 & 0.958 \\
\hline 7 & Financial Institutions & 76 & 2.895 & 10 & 1.001 \\
\hline 8 & Media & 76 & 2.987 & 9 & 0.945 \\
\hline 9 & $\begin{array}{l}\text { Policy makers (including the Members } \\
\text { of Parliament) }\end{array}$ & 76 & 3.921 & 6 & 0.762 \\
\hline 10 & Environmental groups & 76 & 2.844 & 11 & 0.967 \\
\hline 11 & Society as a whole & 76 & 3.513 & 8 & 1.039 \\
\hline
\end{tabular}

Source: Researcher's Design.

Table 4 shows the level of agreement which is categorized based on the mean score, into three groups. The first group, which consists of stakeholders (1, 2 and 5) were received high level of agreement "strongly agree" on the company's Board is accountable to them, with a mean score of $4.605,4.539$ and 4.513 respectively. The second group of stakeholders $(3,4,6,9$ and 11) were received a level of agreement on the company's Board is accountable to them, less than the first group "agree" (mean score $=4.039,4.013,3.671,3.921$ and 3.513 respectively), while the third group (7, 8 and 10) were received a level of agreement "undecided" with mean score $2.895,2.987$ and 2.844 respectively. According to this discussion, principles of corporate governance fit to some extent with the principles of OCED corporate governance standards, which stress the accountability of a company's Board towards stakeholders.

\section{Stakeholders Role}

In this part of the questionnaire, the participants were asked "To what extent do you agree with the following statements about your company?" The answer is shown in Table 5. 
Table 5. Respondents' Opinion about Stakeholders Role

\begin{tabular}{|l|l|c|c|c|c|}
\hline $\mathbf{N}$ & Statements & $\begin{array}{c}\text { No. of } \\
\text { cases }\end{array}$ & Mean & Rank & $\begin{array}{c}\text { Std. } \\
\text { Deviation }\end{array}$ \\
\hline 1 & $\begin{array}{l}\text { The only real goal of your company is } \\
\text { making profit for shareholders. }\end{array}$ & 76 & 4.184 & 1 & 0.725 \\
\hline 2 & $\begin{array}{l}\text { Your company, besides making profit } \\
\text { for shareholders, also has the goal of } \\
\text { attaining the well-being of other } \\
\text { stakeholders. }\end{array}$ & 76 & 2.75 & 4 & 0.896 \\
\hline 3 & $\begin{array}{l}\text { Responsibility to other stakeholders is } \\
\text { only a concern if it is a legal } \\
\text { requirement. }\end{array}$ & 76 & 2.158 & 6 & 0.910 \\
\hline 4 & $\begin{array}{l}\text { Responsibility to other stakeholders is a } \\
\text { concern because it's company policy. }\end{array}$ & 76 & 4.132 & 2 & 0.680 \\
\hline 5 & $\begin{array}{l}\text { Your company provides equal, timely } \\
\text { and cost-efficient access to relevant } \\
\text { information for all its stakeholders }\end{array}$ & 76 & 2.329 & 5 & 0.999 \\
\hline 6 & $\begin{array}{l}\text { The stakeholders have the opportunity } \\
\text { to obtain effective redress for violation } \\
\text { of their rights. }\end{array}$ & 76 & 3.329 & 3 & 0.661 \\
\hline
\end{tabular}

Source: Researcher's Design.

Different levels of agreement, as appears in Table 5, were reported for the statements related to stakeholders role. Statements 1 and 4 "The only real goal of your company is making profit for shareholders", and "Responsibility to other stakeholders is a concern because it's company policy" were ranked first and second with nearly the same high level of agreement "agree" (mean=4.184 and 4.132). Statements number 6 and 2 "The stakeholders have the opportunity to obtain effective redress for violation of their rights", and "Your company, besides making profit for shareholders, also has the goal of attaining the well-being of other stakeholders" were ranked third and fourth with no agreement "undecided" (mean=3.329 and 2.75 respectively). As for the other two statements (5 and 3) "Your company provides equal, timely and cost-efficient access to relevant information for all its stakeholders", and "Responsibility to other stakeholders is only a concern if it is a legal requirement" were ranked fifth and sixth with a low level of agreement "disagree" (mean=2.329 and 2.158 respectively). Accordingly, statements 1 and 4 fit with the principles of OCED corporate governance standards, which stress the role of stakeholders in corporate governance. Statement number 3, although received a low agreement level "disagree", but it also, fits with the principles of OCED corporate governance standard. On the other hand, statements 2 and 6 which received no agreement "undecided", and statement 5 that reported with disagree are not fit with OCED principles. Overall, we can summary that the principle of stakeholders role, to extremely extent, do not fit with OCED principles of corporate governance. 
Disclosure and Transparency

The question related to disclosure and transparency was "To what extent does your company disclose the following information?" and the result is presented in Table 6.

Table 6. Respondents' Opinion about Disclosure and Transparency

\begin{tabular}{|l|l|c|c|c|c|}
\hline $\mathbf{N}$ & Statements & $\begin{array}{c}\text { No. of } \\
\text { cases }\end{array}$ & Mean & Rank & $\begin{array}{c}\text { Std. } \\
\text { Deviation }\end{array}$ \\
\hline 1 & $\begin{array}{l}\text { The financial and operating results of } \\
\text { the company. }\end{array}$ & 76 & 4.632 & 1 & 0.486 \\
\hline 2 & Company objectives. & 76 & 4.342 & 2 & 0.601 \\
\hline 3 & $\begin{array}{l}\text { Major share ownership and voting } \\
\text { rights. }\end{array}$ & 76 & 4.145 & 3 & 0.687 \\
\hline & $\begin{array}{l}\text { Information about board members, } \\
\text { including their qualifications, the } \\
\text { selection process, other company } \\
\text { directorships and whether they are } \\
\text { regarded as independent by the board. }\end{array}$ & 76 & 2.829 & 7 & 0.900 \\
\hline 5 & $\begin{array}{l}\text { Remuneration policy for members of } \\
\text { the board and key executives. }\end{array}$ & 76 & 2.632 & 8 & 0.814 \\
\hline 6 & Predictable risk factors & 76 & 3.053 & 5 & 0.671 \\
\hline 7 & Governance structures and policies. & 76 & 3.934 & 4 & 0.914 \\
\hline 8 & $\begin{array}{l}\text { The impact of the company's activities } \\
\text { on society and the environment. }\end{array}$ & 76 & 2.842 & 6 & 0.731 \\
\hline
\end{tabular}

Source: Researcher's Design.

The results related to the principle "disclosure and transparency" can be divided into two groups. The first group which consists of statements (1, 2, 3 and 7) were received high level of agreement "strongly agree" and "agree". Statements 1 and 2 "The financial and operating results of the company" and "Company objectives" were received an agreement of "strongly agree" (mean score > 4.20), while statements (3 and 7) "Major share ownership and voting rights" and "Governance structures and policies" were received an agreement of "agree" (mean score between 3.40-4.20). These statements of this principle do strongly fit with the OCED principles of corporate governance. The second group which consists of statements $(4,5,6$, and 8$)$ were received no agreement "undecided". Statements of the second group, in contrast with statements of the first group, don fit with the OCED principles of corporate governance. Accordingly, this principle, to some extent, does not fit with OCED principles of corporate governance.

\section{The Board of Director}

This part of the questionnaire consists of five questions. The first question was "To what extent do you agree that the following factors impact the selection process of directors in your company?" The participants' responses are presented in Table 7. 
Table 7. Respondents' Opinion about the Selection of Company Directors

\begin{tabular}{|l|l|c|c|c|c|}
\hline $\mathbf{N}$ & Statements & $\begin{array}{c}\text { No. of } \\
\text { cases }\end{array}$ & Mean & Rank & $\begin{array}{c}\text { Std. } \\
\text { Deviation }\end{array}$ \\
\hline 1 & Shareholders & 76 & 4.421 & 1 & 0.497 \\
\hline 2 & Kinship & 76 & 1.816 & 7 & 0.668 \\
\hline 3 & Favoritism and Nepotism & 76 & 2.053 & 6 & 0.826 \\
\hline 4 & $\begin{array}{l}\text { Personal compatibility with board } \\
\text { members }\end{array}$ & 76 & 3.118 & 4 & 0.765 \\
\hline 5 & Advice from consultants & 76 & 2.184 & 5 & 0.934 \\
\hline 6 & Experience and qualifications & 76 & 4.026 & 2 & 0.783 \\
\hline 7 & Business relationship & 76 & 3.211 & 3 & 0.618 \\
\hline 8 & Reputation & 76 & 4.026 & 2 & 0.730 \\
\hline
\end{tabular}

Source: Researcher's Design.

The survey results show that shareholders were considered to have the most significant factor in the selection of a company directors, with a high level of agreement "strongly agree" (mean score=4.421). Selection of company directors by "Experience and qualifications" and "Reputation" came second, with a high level of agreement "agree" (with the same mean score 4.026). Factors (4 and 7) "Personal compatibility with board members" and "Business relationship" received no agreement "undecided" with mean score (3.118 and 3.211 respectively), while factors (2, 3 and 5) "Kinship", "Favoritism and nepotism" and "Advice from consultants" received an agreement of disagree (mean score $=1.816,2.053$ and 2.184 respectively). Accordingly, this result to extremely extent fit with OCED principles of corporate governance.

The second question of this part was "Does the CEO of your company also serve as Board Chairman?" The answer of this question was (No) from all respondents. This result reflects a good corporate governance practice, as the most advanced corporate governance codes of conduct (e.g., UK Combined Code on Corporate Governance and US Sarbanes-Oxley legislation) recommend separating the roles of chair and chief executive officer.

The third question was "How is your board composed and how frequently does the Board of Directors meet?" All respondents indicated that the board is composed only from non-executive members (this result strongly fit with the previously result). 34 respondents $(44.74 \%)$ stated that the Board of Directors meet every three months, 32 respondents $(42.11 \%)$ perceived that the Board of Directors meet every month, while the rest of respondents $(13.15 \%)$ reported that the Board of Directors meet every six months.

The fourth question was "In your company, how are the executive directors selected? Most of respondents $85.53 \%$ (65) illustrated that the executive directors are selected by board of directors, while the other perceived that the selection is by major shareholders. This result reflects that the executive directors are more independent rather than selected by major shareholders. According to the argument of the last three questions, it appears clearly that these results fit with the OCED principles of corporate governance. 
The last question of this part was "To what extent do you agree that your company's board is doing the following? This question was set to elicit data about the nature of the board work.

Table 8. Respondents' Opinion about the Nature of the Board Work

\begin{tabular}{|c|c|c|c|c|c|}
\hline $\mathbf{N}$ & Statements & $\begin{array}{l}\text { No. of } \\
\text { cases }\end{array}$ & Mean & Rank & $\begin{array}{c}\text { Std. } \\
\text { Deviation }\end{array}$ \\
\hline 1 & $\begin{array}{l}\text { Reviews corporate strategy, major } \\
\text { plans of action, risk policy, and } \\
\text { annual budgets. }\end{array}$ & 76 & 4.381 & 1 & 0.489 \\
\hline 2 & Sets the corporate objectives. & 76 & 4.197 & 5 & 0.589 \\
\hline 3 & Monitors the corporate performance. & 76 & 4.263 & 2 & 0.526 \\
\hline 4 & $\begin{array}{l}\text { Exercises objective independent } \\
\text { judgment on corporate affairs. }\end{array}$ & 76 & 4.224 & 4 & 0.532 \\
\hline 5 & $\begin{array}{l}\text { Selects, compensates, monitors and, } \\
\text { when necessary, replaces key } \\
\text { executives. }\end{array}$ & 76 & 4.184 & 6 & 0.605 \\
\hline 6 & Treats all shareholders fairly. & 76 & 3.724 & 8 & 0.776 \\
\hline 7 & $\begin{array}{l}\text { Discloses any material interests in } \\
\text { transactions or matters affecting the } \\
\text { corporation. }\end{array}$ & 76 & 3.395 & 9 & 0.953 \\
\hline 8 & $\begin{array}{l}\text { Acts on a fully informed basis, in } \\
\text { good faith, with due diligence and } \\
\text { care, and in the best interest of the } \\
\text { company and the shareholders. }\end{array}$ & 76 & 4.158 & 7 & 0.567 \\
\hline 9 & $\begin{array}{l}\text { Ensures compliance with relevant } \\
\text { law and takes into account the } \\
\text { interests of all stakeholders. }\end{array}$ & 76 & 4.237 & 3 & 0.513 \\
\hline
\end{tabular}

Source: Researcher's Design.

As can be seen in Table 8, all statements related to the nature of the board directors work (except number 7) received a high level of agreement "strongly agree" and "agree" (mean score > 3.4). As for statement 7 "Discloses any material interests in transactions or matters affecting the corporation" received no agreement "undecided" with mean score=3.395 (nearly of the range "agree"). To summary the result of sixth principle of corporate governance "the Board of Directors", we can say, depending on the discussion of these five questions, this principle fit with the OCED principle of corporate governance.

\section{The Main Obstacles Associated with Corporate Governance Practice}

The participants were given several possible obstacles that might impede corporate governance practice (with option of others), and were asked to indicate the extent to which they agreed that these obstacles limiting the application of corporate governance in companies listed on the Libyan stock market. The results of the perceptions of the participants about these obstacles are presented in Table 9. 
Table 9. Respondents' Opinion about the Obstacles Associated with Corporate Governance Practice

\begin{tabular}{|l|l|c|c|c|c|}
\hline $\mathbf{N}$ & Statements & $\begin{array}{c}\text { No. of } \\
\text { cases }\end{array}$ & Mean & Rank & $\begin{array}{c}\text { Std. } \\
\text { Deviation }\end{array}$ \\
\hline 1 & $\begin{array}{l}\text { Weakness of using modern } \\
\text { management methods. }\end{array}$ & 76 & 3.092 & 8 & 0.926 \\
\hline 2 & $\begin{array}{l}\text { Weakness of focus on specialization } \\
\text { in corporate management. }\end{array}$ & 76 & 3.447 & 6 & 0.885 \\
\hline 3 & $\begin{array}{l}\text { Insufficient laws and procedures } \\
\text { governing the work of companies. }\end{array}$ & 76 & 2.118 & 10 & 0.864 \\
\hline 4 & $\begin{array}{l}\text { Shortage of knowledge of the concept } \\
\text { and requirements of corporate } \\
\text { governance. }\end{array}$ & 76 & 3.868 & 4 & 0.869 \\
\hline 5 & $\begin{array}{l}\text { Lack of educational programs on } \\
\text { corporate governance. }\end{array}$ & 76 & 3.974 & 3 & 0.673 \\
\hline 6 & $\begin{array}{l}\text { The negative impact of some aspects } \\
\text { of culture and social relations in } \\
\text { Libyan society on the performance of } \\
\text { companies. }\end{array}$ & 76 & 3.671 & 5 & 0.806 \\
\hline 7 & $\begin{array}{l}\text { Lack of compliance with the laws } \\
\text { governing the work of companies. }\end{array}$ & 76 & 4.382 & 1 & 0.765 \\
\hline 8 & $\begin{array}{l}\text { High cost of applying corporate } \\
\text { governance rules. }\end{array}$ & 76 & 4.276 & 2 & 0.665 \\
\hline 9 & $\begin{array}{l}\text { Lack of clear policy emphasizes } \\
\text { adherence to moral conduct. }\end{array}$ & 76 & 3.289 & 7 & 0.780 \\
\hline 10 & $\begin{array}{l}\text { Weakness of incentives and rewards } \\
\text { system for boards of directors. }\end{array}$ & 76 & 2.276 & 9 & 0.918 \\
\hline
\end{tabular}

Source: Researcher's Design.

As can be seen in Table 9, statements number 7 "Lack of compliance with the laws governing the work of companies" and number 8 "High cost of applying corporate governance rules" were perceived to be the most important obstacles impeding corporate governance practice in companies listed in the Libyan stock market with high level of agreement "strongly agree" (mean score $=4.382$ and 4.276 respectively). Statements 2, 4, 5 and 6, also, received high level of agreement "agree" with mean score between 3.40 to 4.20. As for other obstacles listed in this table, statements number 1 "Weakness of using modern management methods" and number 9 "Lack of clear policy emphasizes adherence to moral conduct" received no agreement "undecided" to be obstacles for corporate governance practice in these companies (mean $=3.092$ and 3.289, respectively), while statements number 3 "Insufficient laws and procedures governing the work of companies" and number 10 "Weakness of incentives and rewards system for boards of directors" were perceived to be no obstacles impeding corporate governance practice in the companies under investigation (mean score less than 2.60). Accordingly, we can conclude that statements 2, 4, 5, 6, 7, and 8 are the main obstacles that impede corporate governance practice in companies listed in the Libyan stock market (mean score greater than 3.40). 


\section{Conclusion}

Corporate governance has been the main area of research during the last three decades, but the available literature on corporate governance in developing countries is little compared with the existing literature in developed countries. This study tried to cover one aspect of corporate governance in Libya. The study investigated the nature of corporate governance practice in companies Listed on the Libyan stock market, and the obstacles impeding its application. The findings of the questionnaire related to the nature of corporate governance practice showed that (1) the ownership structure in companies listed on the Libyan stock market is concentrated. Hence, this fits poorly with the principles of OCED corporate governance standards; (2) companies under investigation protect shareholders rights. Hence, this fits with the principles of OCED corporate governance standards; (3) the accountability of these companies' board to some extent fits with the principles of OCED corporate governance standards; (4) the stakeholders role, to extremely extent, do not fit with OCED principles of corporate governance; (5) the disclosure and transparency of these companies, to some extent, does not fit with OCED principles of corporate governance; and (6) the responsibilities of the Board fit with the OCED principle of corporate governance. The findings about the obstacles associated with corporate governance practice showed that "weakness of focus on specialization in corporate management", "shortage of knowledge of the concept and requirements of corporate governance", "lack of educational programs on corporate governance", "the negative impact of some aspects of culture and social relations in Libyan society on the performance of companies", "lack of compliance with the laws governing the work of companies" and "high cost of applying corporate governance rules" are the main obstacles that impede corporate governance practice in companies listed in the Libyan stock market.

\section{References}

Al-Wasmi M (2011) Corporate governance practice in the GCC: Kuwait as a case study. $\mathrm{PhD}$ Thesis. England: Brunel University.

Alas R, Elenurm T, Tafel-Viia K (2010) Who is driving change? Corporate governance and organizational change in Estonia. Journal of Baltic Studies 41(1): 23-43.

Aldabbous N (2012) Corporate governance transformation: the case of Kuwait. Doctoral Thesis. Scotland: The University of Aberdeen.

Aljbiri A (2012) The performance of Libyan stock market. Acta Universitatis Agriculturae et Silviculturae Mendelianae Brunensis 60(7): 27-38.

Andreasson S (2009) Understanding corporate governance reform in South Africa: AngloAmerican divergence, the King reports, and hybridization. Business \& Society 50(4): 647-673.

Baklouti N, Gautier F, Affes H (2016) Corporate governance and financial distress of European commercial banks. Journal of Business Studies Quarterly 7(3): 75-96.

Charles C, Oludele A (2003) A review of corporate governance in Africa: literature, issues and challenges. Paper prepared for the Global Corporate Governance Forum, 15 June 2003. 
Chowdhury Saima F (2013) Barriers to good governance in developing countries: the case of Bangladesh. PhD Thesis. UK: University of Birmingham.

Clarke T (2004) Theories of corporate governance: the philosophical foundations of corporate governance. London: Routledge Taylor \& Francis Group.

Da Silveira A, Leal R, Da Silva A, Barros L (2007) Evolution and determinants of firmlevel corporate governance quality in Brazil. Revista de Administração São Paulo 44(3): 173-189.

Du Plessis J, McConvill J, Bagaric M (2005) Principles of contemporary corporate governance. Cambridge: University Press.

Hussain S, Mallin C (2002) Corporate governance in Bahrain. Corporate Governance: An International Review 10(3): 197-210.

Keasey K, Thomposon S, Wright M (1997) Corporate governance; economic, management, and financial issues. Oxford: Oxford University Press.

Lazarides T, Drimpetas E, Koufopoulos D (2009) Ownership structure in Greece: determinants and implications on corporate governance. SSRN Electronic Journal. https://papers.ssrn.com/sol3/papers.cfm?abstract_id=1348508.

Letza S, Sun X, Kirkbride J (2004) Shareholding versus stakeholding: a critical review of corporate governance. Corporate Governance: An International Review 12(2): 242262.

Liew P (2007) Corporate governance reforms in Malaysia: the key leading players' perspectives. Corporate Governance: An International Review 15(5): 724-740.

Mehran H (2003) Corporate governance: what do we know, and what is different about banks. Introduction, Federal Reserve Bank of New York Economic Policy Review 9(1): $1-3$.

OECD (2004) OECD principles of corporate governance. Paris: OECD.

Okpara J (2011) Corporate governance in a developing economy: barriers, issues, and implications for firms. Corporate Governance: An International Review 11(2): 184 199.

Rezaee Z (2009) Corporate governance and ethics. United States: John Wiley \& Sons, Inc.

Singh A (2003) Competition, corporate governance and selection in emerging markets. The Economic Journal 113(491): 443-464.

Solomon J, Solomon A (2004) Corporate governance and accountability. England: John Wiley \& Sons Ltd.

Solomon J (2010) Corporate governance and accountability. United Kingdom: John Wiley \& Sons Ltd.

Sternberg E (2004) Corporate governance: accountability in the marketplace. London: The Institute of Economic Affairs.

Tosuni G (2013) The impact of corporate governance on the performance of financial institutions. $\mathrm{PhD}$ Thesis. England: Staffordshire University.

Wanyama S, Burton B, Hellier C (2009) Frameworks underpinning corporate governance: evidence on ugandan perceptions. Corporate Governance: An International Review 17(2): 159-175. 